\title{
Using Audio Lingual Method to Improve Students Pronunciation Ability of Darul Mahdiah Private School
}

\author{
Kuni Hikmah Hidayati \\ University of Muhammadiyah Jember \\ (kunihikmah@gmail.com)
}

\begin{abstract}
This study aims at finding out how the use Audio Lingual Method through Repetition Drill Technique improves Thai students' pronunciation ability. This is a Classroom Action Research (CAR) conducted in Darul Mahdiah private school Songkhla-Thailand. The subjects of the study are 16 Thai students of class $6 / 2$ at the school. The data were collected from pronunciation tests and analyzed by using percentages analysis. The result of the students' pronunciation improvement was as follows; in the pre-pronunciation test the students' pronunciation score was $0 \%$ (excellent), $0 \%$ (very good), $31.25 \%$ (good), $31.25 \%$ (low) and $37.5 \%$ (failed), in the cycle 1 post test the score was $0 \%$ (excellent), $14.29 \%$ (very good), $50 \%$ (good), $21.42 \%$ (low) and $14.29 \%$ (failed), and the score of the cycle 2 post test was $6.25 \%$ (excellent), $37.5 \%$ (very good), $43.75 \%$ (good), 12.5\% (low) and 0\% (failed). This leads to the conclusion that the students' improved pronunciation was due to the two reasons; first, the students' pronunciation ability improved through repetition drill since they got used to pronounce words intelligibly as what the teacher modeled.
\end{abstract}

Keywords: audio lingual method, repetition drill, pronunciation, thai students

Pronunciation is undeniably important in a communication. Learners with good pronunciation in English are more likely to be understood even if they make errors in other areas, whereas learners whose pronunciation is difficult to understand will not be understood, even if their grammar is perfect (Yates, 2002). Being in line with the statement, Yates and Zielinski (2009, p. 11) state, "It does not matter how good a learner's vocabulary or grammar is if no one can understand them when they speak". However, taking into account what has been stated, this does not mean to say that vocabulary and grammar are not important at all, but good communication will still exist with only simple vocabulary and grammar.

Unlike vocabulary and grammar, however, pronunciation does not offer the word "simple" in good communication, but should be intelligible instead. Intelligible pronunciation, moreover, means one's pronunciation is clear enough to be understood (Hornby, 2010). It helps us understand others' English and, therefore, enables us to communicate with English natives and non-natives (Wei and Zhou, 2002). One, consequently, does not need to sound like a native speaker of English in order to build good communication but to be intelligible (Lynch and Anderson, 2012). Thus, intelligible pronunciation is a need and, therefore, this criterion of intelligible, then, becomes the aim of this study to improve students' pronunciation.

The need for intelligible pronunciation 
seems to be always a problem, however. Even though it is true that intelligible pronunciation does not mean to sound perfectly like a native speaker of English, but pronunciation is considered difficult, indeed. Lynch and Anderson (2012) believe, "anyone who speaks another language will know it can be difficult to produce certain sounds that we do not use in our first language". In addition, Haycraft (1991) in Wei and Zhou (2002) reports that there was a survey of 500 adult students from Cordoba, Barcelona, Paris, Turin and Rome conducted in 1973, one of the questions asked was 'What do you find most difficult in English: "Grammar", "Speaking", "Understanding", "Pronunciation", "Idiom", "Writing"?' Among these alternatives 'Pronunciation' was in a substantial majority.

This also happens in Thailand where English is a foreign language. Mostly Thai students have problems in pronunciation (Wei and Zhou, 2002; Yangklang, 2006; Kanokpermpoon, 2007; and Khamkhien, 2010). Wei and Zhou (2002) further mentioned that Thai students as well as Thai people mostly use borrowed English words, but pronounced in Thai ways, for example, Top land (without $/ \mathrm{d} /$ ), supermarket (without $/ \mathrm{t} /$ ), Lotus (without $/ \mathrm{s} /$ and $/ \mathrm{t}$./ as $/ \mathrm{d} /$ ), etc. Moreover, Yanglang (2006) found that the final consonant sounds in most Thai words are dropped by the students. For example, the words "fine", "find" and "file" are all pronounced similarly. This is also due to the fact that there is no final -l consonant in Thai language, Thai people tend to sound final -l with nasal -n or even omit it, such as ball - /bç ${ }^{\top} \mathrm{II} /$ pronounced as /bçn/ and call - / $\mathrm{kç} / \mathrm{lI} /$ pronounced as $/ \mathrm{khç}^{\top} /$ (Ronakiat, 2002, in Kanokpermpoon 2007, p. 64).

The problems reported by the previous studies, moreover, were faced by the students of Darul Mahdiah School as well, where this study had been conducted. They were the students of class $6 / 2$ in particular. This was obviously found by the researcher who had been teaching the class for more than three months in her assignment of practice teaching. She, for instance, had found that most of the students pronounced the word "noodle" as /'nu:.dn/ instead of /'nu:.dl / and that the word "go" was pronounced as / kou/ instead of / gou/, etc.. This had made the researcher hardly understood their pronunciation at first.

The researcher, however, found that there have been some studies focused on Thai students' English pronunciation as the result of taking into account the existence of the pronunciation problems. Wei and Zhou (2002) has found that English pronunciation is a problem for Thai students to some extent. This, moreover, is in line with Kanokpermpoon (2007) who investigated Thai and English consonants and found that Thai consonants that differ from that of English are challenging for Thai people in certain pronunciation. Another study on pronunciation, meanwhile, has been conducted towards Thai students of Science field related to their pronunciation ability through word stress assignment (Khamkhien, 2010).

However, the current study should be taken into account since pronunciation of Thai students has been investigated by the previous researchers to be still a problem and needed solving. The result of this study is, then, expected to ensure how this method must be considered to solve pronunciation problems in the future. Besides, this study is accounted to be significant, since there had not been any studies investigating and solving students' pronunciation problems in the selected school. In addition, the researcher conducted researcher's own teaching and observation in order to ensure the success of this study.

The last but not least, it is believed that Audio Lingual Method will be best applied to solve the students' pronunciation problems in the class, since one of the technique used in the method is "Repetition Drill" technique which makes the students get familiar and used to pronounce the correct English words. This way is accounted suitable for them as the most factor affects students' pronunciation is their native language compared to other factors such as age, motivation, exposure, 
etc.. This has been mentioned by Kenworthy (1987) that the native language is the most influential factor in accounting for students' pronunciation especially foreign accents (Khamkhien, 2010). It is, then, expected that by repeating the correct words the teacher models, the students will realize the correct pronunciation as well as get used to pronounce it for later. In addition to that, during the class sessions, the teacher will have the dominant role which means she does not only model the students pronouncing correct words but also "control" them by correcting their mistakes directly, asking to repeat individually as well as in group, and provide any ways to keep them focus. This means to say that Audio Lingual Method is the proper method to solve the $6 / 2$ students' pronunciation problems.

The problem this study aimed to answer is how the use of Audio Lingual Method in listening class can improve pronunciation ability of Darul Mahdiah private school students in the 2014/2015 academic year. Therefore, the objective of this study is to find out how Audio Lingual Method can improve pronunciation ability of Darul Mahdiah private school students in the 2014/2015 academic year.

\section{Method}

Since this study is a classroom action study, its procedures, therefore, comprised cycle I and cycle II to complete. Each cycle consists of planning, acting, observing and reflecting. Besides, before conducting the cycles, the preliminary study had been done by conducting a short interview with the English teacher and pre test. The result of the interview was that the teacher generally realized the students' pronunciation problems but had not tried to observe what the problems in detail. After doing the interview, the researcher conducted the pre test as she would like to know the students' pronunciation problems in detail. The test was designed to find out what English sounds were challenging (problems) for them. From the result of the test, the researcher found out that the challenging words for Thais generally were challenging for them as well, especially the English sounds that they found not exist in their native language and borrowed English words such as apple, van, etc.

Afterwards, the cycles were done by fulfilling four procedures, planning, acting, observing and reflecting. In the planning, it was to plan the lesson and the observation list that would be used in teaching. It was Thai curriculum used. This study conducted in three meetings which comprises introduction in the first meeting, strengthening in the second, and the post test as the evaluation in the third one. In addition, as other subjects were provided, the school provided 60 minutes for each meeting for this study implementation as written in the lesson plan. Later, between the researcher and her collaborator, one was teaching the students and the other was observing; both the teacher and the students. The last but not least is the reflection in which the researcher along with her collaborator analyzed the data that had been collected. The data used in this study were observation list and pronunciation test. The analysis is as the following formulas:

The observation list was analyzed by considering the rate 1,2 and 3.1 means very few of the students do the indicator, 2 means some of them do, and 3 means all or majority of the students do it. The result would be as the reflection.

The students' pronunciation test score was analyzed by using percentages with qualifications as follow:

\begin{tabular}{cc}
\hline Interval & Qualification \\
\hline$\geq 80$ & Excellent \\
\hline $70-79$ & Very Good \\
\hline $60-69$ & Good \\
\hline $51-59$ & Low \\
\hline$\leq 50$ & Failed \\
\hline
\end{tabular}


Those who were qualified as good, very good and excellent (scored $\geq 60$ ) were considered achieving the target score. Thus, to know if the cycle was successful the number of students scored $\geq 60$ was counted into percentages as follows:

$$
E=\frac{n}{N} 100 \%
$$

Which:

$E=$ the percentage of student who achieve the target score of $\geq 60$

$n=$ the number of students achieving the minimum standard scores

$\mathrm{N}=$ the total number of students

(Ali, 1993, p. 186)

In reflecting was the decision made by the researcher along with her collaborator whether the cycle was stopped or continued to the next one. In other words, it was going to decide if the teaching by using Audio Lingual Method had already improved the students' pronunciation achieving the score of criterion of success or not. Anything found in the reflection, moreover, was the consideration (revised) for the next ones.

\section{Result and Discussion}

The result of the students' pronunciation tests were analyzed into several qualifications based on some intervals; $\geq 80$ was considered excellent, 70-79 was very good, 60-69 was good, 51-59 was low and $\leq 50$ was failed qualification. Thus, the pronunciation test in the preliminary study was analyzed as follows:

Since the target score of the study was $\geq 60$, then those who had achieved at least "Good" category were considered had achieved the score. Thus, in the preliminary study there were only $31.25 \%$ of the total number of the students being qualified as good who had achieved the target score as provided in the table. Afterwards, the pronunciation score of cycle 1 and 2 would be analyzed in the same way in the next sections.
Table 1. The Pronunciation Test of Preliminary Study

\begin{tabular}{cccc}
\hline \multirow{2}{*}{ Interval } & $\begin{array}{c}\text { Qualifi- } \\
\text { cation }\end{array}$ & $\begin{array}{c}\text { Pumber } \\
\text { of Stu- } \\
\text { dents }\end{array}$ & $\begin{array}{c}\text { Percent- } \\
\text { ages }\end{array}$ \\
\hline$\geq 80$ & Excellent & - & $0 \%$ \\
\hline $70-79$ & $\begin{array}{c}\text { Very } \\
\text { Good }\end{array}$ & - & $0 \%$ \\
\hline $60-69$ & Good & 5 & $31.25 \%$ \\
\hline $51-59$ & Low & 5 & $31.25 \%$ \\
\hline$\leq 50$ & Failed & 6 & $37.5 \%$ \\
\hline
\end{tabular}

\section{Pronunciation Test in Cycle 1}

The following chart describes the students' score of cycle 1 post test.

The $35.71 \%$ is the percentage of the number of the students who scored lower than 60 , meaning that there are five students had not achieved the target score. While the $64.29 \%$ was the percentage of those scored $\geq 60$ which means nine students had achieved the target score. Afterwards, the detail of those achieving the target score of $\geq 60$ or qualified as good, very good or excellent and those qualified as low and failed who were scored below 60 was in table 2 below.

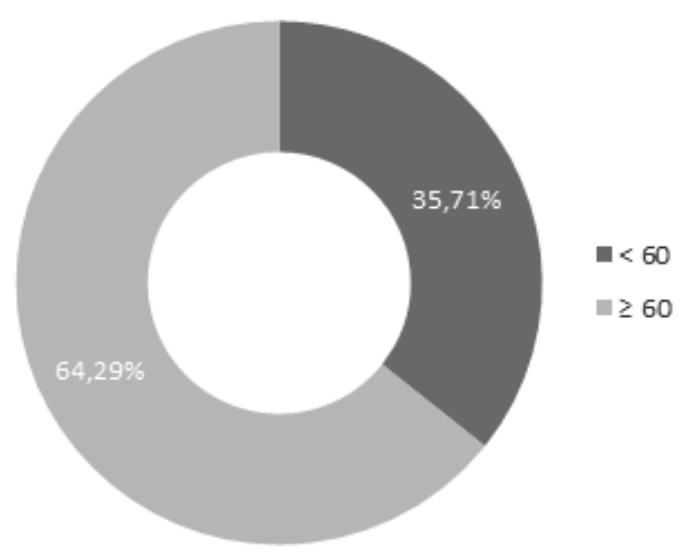

Figure 1. The Result of Cycle 1 Post Test 
Table 2. The Pronunciation Test of Cycle 1

\begin{tabular}{cccc}
\hline \multirow{2}{*}{ Interval } & $\begin{array}{c}\text { Qualifi- } \\
\text { cation }\end{array}$ & $\begin{array}{c}\text { Number } \\
\text { of Stu- } \\
\text { dents }\end{array}$ & $\begin{array}{c}\text { Percent- } \\
\text { ages }\end{array}$ \\
\hline$\geq 80$ & Excellent & - & $0 \%$ \\
\hline $70-79$ & $\begin{array}{c}\text { Very } \\
\text { Good }\end{array}$ & 2 & $14.29 \%$ \\
\hline $60-69$ & Good & 7 & $50 \%$ \\
\hline $51-59$ & Low & 3 & $21.42 \%$ \\
\hline$\leq 50$ & Failed & 2 & $14.29 \%$ \\
\hline
\end{tabular}

Table 2 above describes the $64.29 \%$ of the 14 students who had achieved the target score and another $35.71 \%$ of them who had not achieved it yet in detail; $0 \%$ (excellent), $14.29 \%$ (very good), 50\% (good), $21.42 \%$ (low) and $14.29 \%$ (failed). The conclusion, therefore, was $64.29 \%$ of the number of students had achieved the target score that were qualified as good (50\%) and very good (14.29\%). This suggests that the cycle 1 was considered failed.

As mentioned above, there were two possible defects affecting the failure of cycle 1. Firstly, the students did not practice the pronunciation perfectly due to the punctuality of the teaching could not be as what had been planned. This was because the use of $100 \%$ English in the teaching makes the students hardly understand some of the instructions given. Secondly, the material being taught include some words that were not familiar so that they could not repeat the teacher well. The first cycle was, therefore, unsuccessful.

\section{Pronunciation Test in Cycle 2}

The following chart describes the 14 students (87.5\%) achieving the target score which brought about the success of this study and, therefore, the cycle was stopped.

The figure 2 describes the $87.5 \%$ of the total number of the students who had achieved the

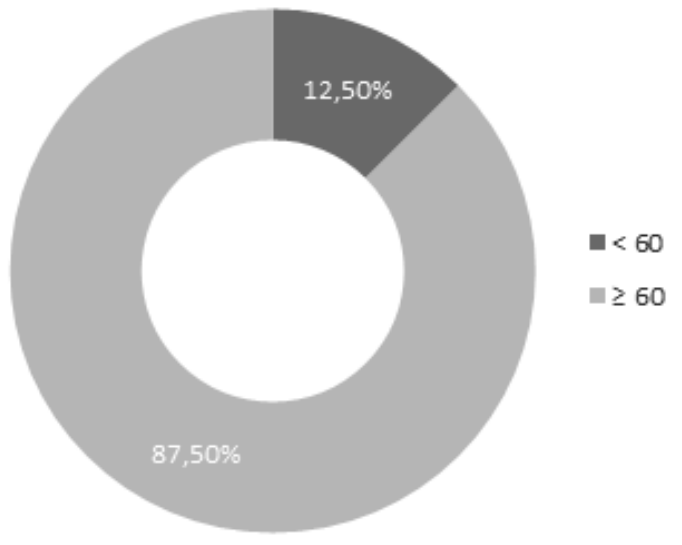

Figure 2. The Result of Cycle 2 Post Test

target score and another $12.5 \%$ who had not achieved it yet. The following table is the detail of the percentages based on each qualification.

Table 3 describes the $6.25 \%$ (excellent), $37.5 \%$ (very good), $43.75 \%$ (good), $12.5 \%$ (low) and $0 \%$ (failed) of the 16 students joining the pronunciation test. This confirms the success of the cycle 2 since there had been $87.5 \%$ or 14 students who had achieved the target score that were qualified as good (43.75\%), very good (37.5\%), and excellent (6.25\%). In addition, there was none of the students qualified as failed, and only $12.5 \%$ or 2 students qualified as low. Cycle 2 was, then, successful.

Table 3. The Pronunciation Test of Cycle 2

\begin{tabular}{cccc}
\hline \multirow{2}{*}{ Interval } & $\begin{array}{c}\text { Qualifi- } \\
\text { cation }\end{array}$ & $\begin{array}{c}\text { Pumber } \\
\text { of Stu- } \\
\text { dents }\end{array}$ & $\begin{array}{c}\text { Percent- } \\
\text { ages }\end{array}$ \\
\hline$\geq 80$ & Excellent & 1 & $6.25 \%$ \\
\hline $70-79$ & $\begin{array}{c}\text { Very } \\
\text { Good }\end{array}$ & 6 & $37.5 \%$ \\
\hline $60-69$ & Good & 7 & $43.75 \%$ \\
\hline $51-59$ & Low & 2 & $12.5 \%$ \\
\hline$\leq 50$ & Failed & - & $0 \%$ \\
\hline
\end{tabular}




\section{The Improvement of Students' Pronunciation} Ability

Pronunciation ability in the study refers to the ability of 16 Thai students to pronounce English words. Since the students' pronunciation ability was mostly found unintelligible, Audio Lingual Method was expected to improve their pronunciation ability to be intelligible. The overall result, then, has proven that Audio Lingual Method through repetition drill technique helped the students get used to pronounce words intelligibly. This is like Lynch and Anderson (2012, p. 11) state that pronouncing words several times make us familiar with the words and therefore get used to pronounce them as what we often practice. This was proven from the result of the post test in cycle 1 and 2 that in cycle 2 post test the students get improved more than in cycle 1 , and in cycle 1 post test they get improved more than in the pre-pronunciation test. This means that the more they practice the words, the better they can pronounce them.

In addition, there are several Audio Lingual Method principles explaining how Audio Lingual Method improved the students' pronunciation ability, as follows;

Teacher-centered learning refers to the role of the teacher of conducting, guiding, and controlling the students' behavior in the target language. In the case of the students' pronunciation who are Thais supported the objective of the study to improve it. This is because the teacher-centered learning meaning that the students were "forced" to get everything from the teacher only; the teacher modeled to pronounce words, guided and controlled any activities in class to ensure that the students imitate what the teacher modeled. The teachercentered learning, indeed, was appropriate with the subjects of the study due to the need of the subjects as beginners (Brown, 2000, p. 99).

However, about the teacher-centered learning, Richard and Rodgers (2001) state that Audio Lingual Method was considered boring by the students and therefore lost its prestige in the second half of 1960s. The researcher, therefore, prevented this to happen by providing variations in teaching. Providing variations, indeed, keeps the students interested in the learning (Nation, 1974, p. 21). The variations were the variation of the class management, the teacher's voice while modeling the students to pronounce words and giving such rewards to them. By this way, the boredom that the students might feel was solved. For instance, as the teacher gave variations to her voice while modeling the students to pronounce words, which was intended to give the sense of humour and make the students not shy, the students indeed laughed and enjoyed the learning, and this affected to their confidence while practicing afterwards.

Moreover, not only that they were more confident in practicing that the researcher has found out, but also that they were more independent in learning as one of positive impacts after the teaching of Audio Lingual Method. Thus, the teacher centered learning is indeed suitable for them as beginners; they might need the teacher a lot in the class learning, but after the class the researcher found out that they tried to practice themselves as what they had practiced of pronunciation in class. They, for instance, told their friends on the way home by telling them, "I can pronounce the word ball well now, can you do that too?" or that they told the researcher the next day after the teaching that they practiced in front of mirror and let the researcher knew how well they did by practicing in front of her. Besides, this was also proven from the result of the observation list as well that they were enthusiastic more and more during the teaching.

Behaviorism believes that learning is a habit formation. Therefore, the teacher corrected the students immediately after they made mistakes in teaching pronunciation by using ALM. Making mistakes would only make the students form bad habit, in this case is the habit of pronouncing words incorrectly. By correcting the students as they made mistakes indeed supported this study's success as well. This was due to the nature of pronunciation 
ability. As the students were let to make mistakes in pronouncing words, they would record it in mind and heart and would always pronounce the words that way. Therefore, by correcting them, they would get used to pronounce the correct pronunciation of words ever.

Thai is the students' native language and, therefore, was really avoided from using in the teaching of English pronunciation in this study. This actually "forced" the students to get used to listening to English words and motivated as well. As they practiced pronouncing words, later, they would be confident repeating after the teacher since the teacher hooked them to speak up with English. The students, moreover, also loved the way the teacher gave them feedback when they did the activities well such as by praising them saying "How good you are" in English rather than saying it in Thai.

Some plosives are challenging for the students while others are not; Voiceless plosives such as "pen", "key" and "tin" were found as not difficult at all to pronounce by the students. However, the /p/, / $/$ and / $/ \mathrm{k} /$ in the final position were found to be quite a problem to pronounce, but still intelligible enough, such as the word "shop". Another problem also occurred as the students pronounced voiced plosives of /g/ which mostly replaced by the sound of $/ \mathrm{k} /$ since the sound $/ \mathrm{g} /$ does not exist in Thai (Kanokpermpoon, 27, p. 59) e.g. "good" was pronounced as [kú:t] instead of [gúd], "ago" was pronounced as [à ko;] instead of [ $\partial$ 'g $\partial u$ ].

Nasals $/ \mathrm{m} /$ and $/ \mathrm{n} /$ are actually not a problem for the students, but $/ \mathrm{n} /$ is a problem when it exists in the middle of a word (Kanokpermpoon, 27). This study, moreover, found out the same thing that $/ \mathrm{y} /$ is a problem in a word such as "singer" and "hanger". However, they were mostly still pronounced intelligibly unless the students who omitted the sound $/ \mathrm{r} /$ at all that made the researcher hardly understood.

From the result of both post tests in cycle 1 and 2 of this study, fricatives were found the most challenging for the students;
1. Voiceless fricatives $/ \theta /$ and $/ \int /$, for instance, are problems such in the words "thin" "thanks" and "shoe".

2. Voiceless fricatives at final position $/ \theta /, / \int /$, /s/ and /f/ are also problems e.g. "puff" "breath" and "kiss" etc.

3. Voiced fricatives at initial, medial and final positions are problems as well, e.g. "van" "then" "zoo" and "genre" (initial position), "breathing" (medial), "please" (final)

These were found the most challenging for them among all manners of articulation tested. Affricatives / $/ \mathrm{t} /$ and $/ \mathrm{d} 3 /$ such as the word "church" and "George" were quite a problem for the students. Meanwhile in the words "teacher", "child" and "jam", they found less difficult to pronounce. They, however, tend to replace the sound $/ \mathrm{ch} /$ in the words with the sound $/ \mathrm{s} /$.

In lateral, the sound /1/ was not a problem at all such as in "ball" and "call" for some students, but they were a problem for the rests. This was due to their unawareness of Thai and English which are different in facing the / $1 /$ sound. In Thai, the sound / $1 /$ in the final position does not exist and was replaced by the sound $/ \mathrm{n} /$ or even omit it (Yanglang, 2006), while in English it does exists. Therefore, they pronounced "ball" as [bçn] and call as [khç"]. However, after the students realized that there exists such sound in English and were drilled again and again, they could pronounce the $/ 1 /$ intelligibly, especially in the final position of words.

The approximants / $\mathrm{r}$ / such as in "read" and "lead" were a problem to pronounce by Thais (Kanokpermpoon, 2007). However, the study found out that this was not a problem for the students to pronounce and could be differentiated as they pronounced it together. This was proven by the result of the prepronunciation and the cycle 1 post test. 


\section{Conclusion}

This thesis was concerned with the improvement of pronunciation of 16 Thai students of elementary school at Darul Mahdiah private school taught by using Audio Lingual Method through repetition drill technique. The students were drilled in pronouncing correct pronunciation of words during two cycles with two meetings of teaching for each. The success of the study was achieved in the cycle 2 with $87.5 \%$ of the total number of the students achieved score $\geq 60$ which only $64.29 \%$ of those achieving the score in cycle 1 . This was after refining the way to have the students practiced in cycle 1 that the students were found out to be more confident practicing in group based on gender, female and male group, and that the use of variations were effective as well, such as the use of the teacher's voice variations while modeling them to give the sense of humour made the students practiced more bravely and confidently. This resulted the success of the study by concluding that drilling the students pronunciation this way resulted the students' independence to practice by themselves after class and bravery to try practicing something hard.

Considering the result of this study, the researcher fully recommended teachers or other researchers to apply Audio Lingual Method in teaching pronunciation to students. However, due to the imperfection of the study, the researcher suggested the following points to be considered:

1. Audio Lingual Method was considered boring. This needs teachers' creativity whether to provide variations, media, etc. in the teaching. The researcher did not use any media in the teaching of the study, but rather on the variations instead. Teachers or other researchers are better try to use media by still considering the principles of the method such as recalling that this method is an oral based approach which spoken comes first before written, so the media might be such a tape, or other audio media.
2. There are some students as the subjects of the study found difficult still in pronouncing some words of fricatives especially the voiced one, such as van, then, etc. after joining the four sessions of teaching in the two cycles. This can be considerations of Thai teachers or researchers to solve, therefore.

3. In the pronunciation test, the subjects of the study were tested by repeating after the researcher pronouncing each word instead of pronouncing the words by themselves. This was due to the fact that more than a half of the class could not read English (writing). Other researchers, however, are recommended to conduct pronunciation test in different ways considering the ability of subjects.

4. Considering the focus of the study which seemed to be more on the students' consonantal sound pronunciation ability, other researchers might continue such study focusing on both consonant and vowel if students face them, indeed.

\section{References}

Ali, M. (1993). Strategi Penelitian Pendidikan. Bandung: Angkasa.

Arikunto, S. (2013). Prosedur Penelitian: Suatu Pendekatan Praktik. Jakarta: PT Rineka Cipta.

Ary, Donald et al. (2010). Introduction to Research in Education Eighth Edition. Canada: Cengage Learning Products.

Backley, P. (2015). Improving your English Pronunciation. Pearson.

Brown, D. (2000). Teaching by Principles: An Interactive Approach to Language Pedagogy (2nd Ed). Longman.

Brown, D. (2004). Language Assessment: Principles and Classroom Practices. Pearson Education. 
Cromwell, P. \& Griffith, S. (2008). Smile 6. International Language Teaching Services.

Field, J. (2005). Intelligibility and the Listener: The Role of Lexical Stress. TESOL Quarterly. 39(3): 399-423.

Fraser, H. (2001). Teaching Pronunciation: A handbook for teachers and trainers. Department of Education Training and Youth Affairs.

Habib, R.B. (2013). (Un) Intelligibility in EIL Pronunciation: An Analysis. IOSR Journal Of Humanities And Social Science. 14(4): 21-26.

Harmer, J. (2002). The Practice of English Language Teaching (3rd Ed Completely Revised and Updated). England. Longman.

Haycraft, B. (1980). The Teaching of Pronunciation: A Classroom Guide.Hong Kong: Wah Cheong Printing Press Ltd.

Hornby, A.S. (2010). Oxford Advanced Learner's Dictionary (International Student's Ed). Oxfprd University Press.

Kanokpermpoon, M. (2007). Thai and English Consonantal Sounds: A Problem or a Potential for EFL Learning?. ABAC Journal. 27(1): 57-66.

Kelly, G (Ed). (2001). How to Teach Pronunciation. Pearson.

Khamkhien, A. (2010). Thai Learners' English Pronunciation Competence: Lesson Learned from Word Stress Assignment. Journal of Language Teaching and Research.1(6): 757-764.

Larsen-Freeman, D. (2003). Techniques and Principles in Language Teaching (2nd Ed). New York: Oxford University Press.

Levis, J. \& LeVelle, K. (2011). Pronunciation and intelligibility: An overview of the conference. In. J. Levis \& K. LeVelle (Eds.). Proceedings of the 2nd Pronunciation in Second Language Learning and Teaching Conference, Sept. 2010. (pp. 1-6), Ames,
IA: Iowa State University.

Lusiani, D. S. (2011). Improving the Seventh Grade Students' Pronunciation by Using Drilling Technique at MTS Al Mujahidi Gumukmas Jember in the 2010 - 2011 Academic Year. A Thesis (Unpublished). Jember: Muhammadiyah University of Jember.

Lynch, T. \& Anderson, K. (2012). Effective English Learning: Unit 8: Pronunciation. University of Edinburgh: English Language Teaching Centre.

Mark, C.T. (2013). The Audio-Lingual Method: An Easy way of Achieving Speech. International Journal of Academic Research in Business and Social Sciences.3(12): 63-65.

Nation, Paul. (1974). Techniques for Teaching Vocabulary. English Teaching Forum.3(12): 18-21.

Nita, S.A. \& Syafei, A.F.R. (2012). Involving Audio-Lingual Method (ALM) and Communicative Language Teaching (CLT) in Teaching Speaking Skill at Junior High School. Journal of English Language Teaching.1(1): 65-73.

Paul, D. (2004). Teaching English to Children in Asia. Hongkong: Longman Asia ELT.

Purwanto, M.N. (1984). Prinsip-Prinsip dan Teknik Evakuasi Pengajaran. Bandung: Remadja Karya Offset.

Richard, J.C. \& Rodgers, T.S. (2001). Approaches and Methods in Language Teaching. Cambridge: Cambridge University Press.

Saeher, et.al. (2012). A Reflection on the Use of Audio Lingual Method with Listening and Pronunciation Course. Chiang Rai: Mae Fah Luang University.

Schaetzel, K. \& Low, E. L. (2009). Teaching Pronunciation to Adult English Language Learners. Washington: Center for Applied Linguistics.

Wei, Y. \& Zhou, Y. (2002). Insights into English Pronunciation Problems of Thai Students. 
Office of Educational Research and Improvement: Educational Resources Information Center.

Yangklang, W. (2006). Improving English Final/-l/ Pronunciation of Thai Students through Computer-Assisted Instruction Program. A Thesis (Unpublished). Suranaree University of Technology.

Yates, L. (2002). What Is Pronunciation?.La Trobe University: Adult Migrant English Program Research Centre.

Yates, L. \& Zielinski, B. (2009). Teaching Pronunciation to adults. La Trobe University: Adult Migrant English Program Research Centre. 